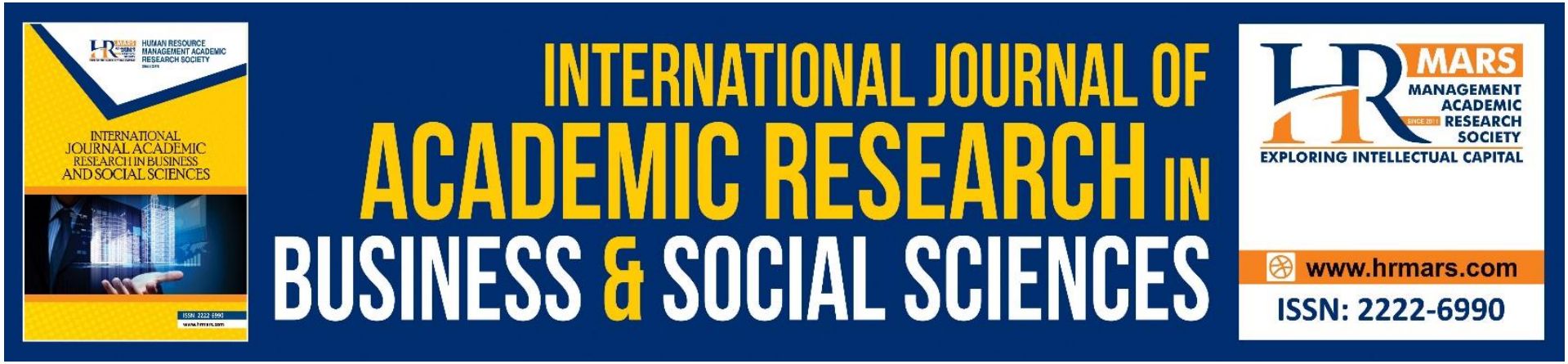

\title{
Review of The Factor Influencing and Measurements of Financial Well-Being
}

Amirah Shazana Magli, Mohamad Fazli Sabri, Husniyah Abdul Rahim, Amirah Shazana Magli

To Link this Article: http://dx.doi.org/10.6007/IJARBSS/v11-i19/11739

DOI:10.6007/IJARBSS/v11-i19/11739

Received: 17 October 2021, Revised: 20 November 2021, Accepted: 10 December 2021

Published Online: 24 December 2021

In-Text Citation: (Magli et al., 2021)

To Cite this Article: Magli, A. S., Sabri, M. F., Rahim, H. A., \& Magli, A. S. (2021). Review of The Factor Influencing and Measurements of Financial Well-Being. International Journal of Academic Research in Business and Social Sciences, 11(19), 310-326.

Copyright: (c) 2021 The Author(s)

Published by Human Resource Management Academic Research Society (www.hrmars.com)

This article is published under the Creative Commons Attribution (CC BY 4.0) license. Anyone may reproduce, distribute, translate and create derivative works of this article (for both commercial and non-commercial purposes), subject to full attribution to the original publication and authors. The full terms of this license may be seen

at: http://creativecommons.org/licences/by/4.0/legalcode

Special Issue Title: Youth and Community Wellness, 2021, Pg. 310 - 326

http://hrmars.com/index.php/pages/detail/IJARBSS

JOURNAL HOMEPAGE

Full Terms \& Conditions of access and use can be found at http://hrmars.com/index.php/pages/detail/publication-ethics 


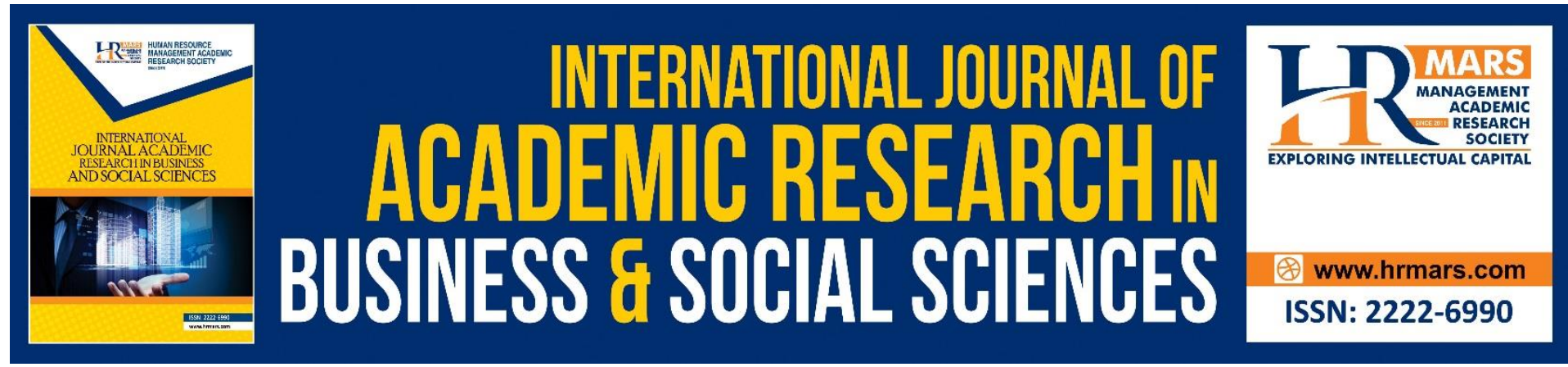

\title{
Review of The Factor Influencing and Measurements of Financial Well-Being
}

\author{
Amirah Shazana Magli², Mohamad Fazli Sabri ${ }^{1,2}$, \& Husniyah \\ Abdul Rahim², Amirah Shazana Magli² \\ ${ }^{1}$ Institute for Social Science Studies, Universiti Putra Malaysia, 43400 UPM Serdang, \\ Selangor, Malaysia, ${ }^{2}$ Department of Resource Management \& Consumer Studies, Faculty of \\ Human Ecology, University Putra Malaysia, 43400 UPM Serdang, Selangor, Malaysia. \\ Email: dean.eco@upm.edu.my, fazli@upm.edu.my, husniyah@upm.edu.my, \\ fazli@upm.edu.my
}

\begin{abstract}
Various indicators have been used to analyse the financial well-being of households during the last few decades (i.e. household income, financial debt, economic, social, financial health, and psychology). Financial well-being, on the other hand, cannot be quantified just on the basis of these few characteristics. It encompasses a variety of factors that influence financial well-being. Thus, this study will examine both objective and subjective qualities, or both subjectively or objectively traits, that contribute to the definition of financial well-being in three selected developed, developing, and underdeveloped countries. The authors conduct a systematic review of the literature (SLR) to inform future research on financial well-being. Identifying prior conceptualisations and definitions of financial well-being was the primary goal of this systemic literature review. Next, the second goal was ascertaining factors that influence financial well-being in three distinct nations. These countries were divided into three categories: developed, developing, and underdeveloped countries. A systematic review enables a researcher to identify the most pertinent papers to address the study issue while minimising errors. As a result of the findings, a subjective method is recognised as a more inclusive technique than an objective approach for defining and measuring a complex and personal phenomenon such as financial well-being. This study is intended to stimulate scholars to continue developing knowledge to enable financial institutions to adopt proactive measures to improve financial well-being.
\end{abstract}

Keywords: Well-Being, Financial Measurement, Systematic Review Literature.

\section{Introduction}

The financial well-being concept is extensively used in many types of research. However, due to its broad perception, there is no comprehensively constructed definition or measurement of financial well-being, particularly on conceptualization and component. In general, financial well-being is defined as having good financial security with freedom of choice and overall satisfaction in present-day and forthcoming (Benjamin et al., 2014). Financial well-being has been examined in the past using a variety of different scales, and the 
literature indicates that it may be classified into two distinct categories: objective and subjective financial well-being.

Nonetheless, throughout literature, mainly researchers are likely to use objective and subjective characteristics, or objective or subjective characteristics, to define financial wellbeing. Conferring to Van Praag, Frijters, and Ferrer-i-Carbonell, (2003), financial well-being has been designated in objective and subjective measures, where they can also be acknowledged as financial wellness (Mokhtar \& Rahim, 2017).

The objective scale of economic statuses is measured using economic status like income, consumption, wealth, and assets. Various researchers used objective scale precisely the amount of money (Williams, 1983), savings and income (Porter, 1990), the comparison between baby boomers and their parents on their income and consumption (Sabelhaus \& Manchester, 1995) and total family income (Fletcher \& Lorenz, 1985) to measure economic well-being.

Variously, previous scholars such as DeVaney and Lytton (1995) and Greninger, Hampton, Kitt, and Achacoso (1996) agreed that an individual's financial well-being could be determined over financial ratio. In contrast, Chen and Finke (1996); Hogarth, Anguelov, and Lee (2004); Porter and Garman (1993) utilized net-worth to measure financial well-being, while Sabri, Cook, and Gudmunson (2012) and Porter and Garman (1993) used financial adequacy (Xiao, 2008).

On the other hand, rendering to Mugenda, Hira, and Fanslow's (1990), subjective measurement was implemented by the majority of studies such as Chan, Yim, and Lam (2010); Delafrooz and Paim (2011a); Sabri et al (2012). Accordingly, subjective well-being measures the level of saving, debt ratio, preparation for financial shocks, consciousness towards the household economic situation, ability to achieve vision and goals, financial management, and preparedness towards financial emergencies (Aripin \& Puteh, 2017).

\section{Selected Recent Papers' on Financial Well-being - Concept Definitions, Study Methods, Sample Size and Main Findings}

This literature review had two related objectives; first, to identify the conceptualisations and definitions of financial well-being used in the past literature. The second aim was to identify the factors influencing and affecting financial well-being across three selected countries - developed, developing and under-developed countries. The summary of variables used to analyse factors influencing financial well-being studies is shown in Table 1.0 and Table 2.0.

In order to meet the stated review objectives, a systematic literature review was conducted using an archival method to examine papers cited in databases such as Google Scholar, SCOPUS, and websites such as Google, Yahoo, and Google Scholar, with financial well-being as the main theme. As a result, this review was conducted as desk research rather than a survey or other research type.

Three significant observations were found in this case. Firstly, a systematic review allows authors to select the most relevant studies to meet the study issue while lowering the 
likelihood of errors. Second, the predetermined inclusion and exclusion criteria are used to identify, select, and evaluate existing empirical research relevant to the review objectives. Duplications are permitted because this process is linked to a structured design. Third, an increase in the number of studies on financial well-being has resulted in inconsistent findings of the idea, measurements, causes, and next steps. As a result, gaining a comprehensive understanding of the topic of financial well-being is challenging.

Table 1.0: A list of the variables found in financial well-being studies

\begin{tabular}{|c|c|c|c|c|}
\hline $\begin{array}{c}\text { List of } \\
\text { countries }\end{array}$ & $\begin{array}{l}\text { Factors or } \\
\text { Variables }\end{array}$ & $\begin{array}{c}\text { Sample } \\
\text { Measurement }\end{array}$ & Methodology & Findings \\
\hline $\begin{array}{c}\text { Developed } \\
\text { Countries } \\
\text { (United } \\
\text { States, } \\
\text { Sweden) }\end{array}$ & $\begin{array}{l}\text { IV } \\
\text { - Self Control } \\
\text { Non-cognitive } \\
\text { variables } \\
\text { - Optimism } \\
\text { (bright, } \\
\text { confidence, } \\
\text { encourage) } \\
\text { - Deliberative } \\
\text { thinking } \\
\text { (Considerate } \\
\text { reasoning) } \\
\\
\text { DV } \\
\text { - Financial } \\
\text { Well-being } \\
\text { - Personal } \\
\text { financial } \\
\text { behaviour }\end{array}$ & $\begin{array}{l}2063 \\
\text { respondents } \\
\text { (1048 women \& } \\
1015 \text { men) } \\
\text { Age } 20-75 \\
\text { Mean age of } 49 \\
\text { years }\end{array}$ & $\begin{array}{l}\text { CMA Research used } \\
\text { a web-based survey } \\
\text { to collect data from } \\
\text { a varied sample of } \\
\text { the adult } \\
\text { population in } \\
\text { Sweden. } \\
\text { - Questionnaire } \\
\text { - OLS regression } \\
\text { - Theory: } \\
\text { Behavioural life- } \\
\text { cycle hypothesis }\end{array}$ & $\begin{array}{l}\text { Individuals' } \\
\text { financial } \\
\text { behaviour and } \\
\text { well-being are } \\
\text { confirmed to } \\
\text { be influenced } \\
\text { by self- } \\
\text { control, } \\
\text { optimism, and } \\
\text { deliberate } \\
\text { thought. } \\
\text { Individuals } \\
\text { believed to } \\
\text { have a high } \\
\text { level of self- } \\
\text { control were } \\
\text { more likely to } \\
\text { engage in } \\
\text { prudent } \\
\text { financial } \\
\text { planning for } \\
\text { future } \\
\text { conditions } \\
\text { and } \\
\text { retirement } \\
\text { plans. } \\
\text { Meanwhile, } \\
\text { optimistic } \\
\text { respondents } \\
\text { worry less } \\
\text { about the } \\
\text { financial } \\
\text { problem and } \\
\text { are } \\
\text { determined } \\
\text { with their } \\
\text { finances. }\end{array}$ \\
\hline
\end{tabular}


INTERNATIONAL JOURNAL OF ACADEMIC RESEARCH IN BUSINESS AND SOCIAL SCIENCES Vol. 11, No. 19, Youth and Community Wellness, 2021, E-ISSN: 2222-6990 @ 2021 HRMARS

\begin{tabular}{|c|c|c|c|c|}
\hline $\begin{array}{l}\text { Developing } \\
\text { Countries } \\
\text { (Malaysia, } \\
\text { Iran) }\end{array}$ & $\begin{array}{l}\text { IV } \\
\text { - Financial } \\
\text { Behaviour } \\
\text { - Financial } \\
\text { Stress } \\
\text { - Financial } \\
\text { Knowledge } \\
\text { - Work } \\
\text { environment } \\
\text { DV } \\
\text { Financíp } \\
\text { Well-being }\end{array}$ & $\begin{array}{l}500 \quad \text { public } \\
\text { employees }\end{array}$ & $\begin{array}{l}\text { - The use of an } \\
\text { internet-based } \\
\text { online survey } \\
\text { - Multiple } \\
\text { regression and } \\
\text { descriptive } \\
\text { statistics } \\
\text { - Exploratory Data } \\
\text { Analysis (EDA) } \\
\text { (i.e., normality, } \\
\text { linearity, } \\
\text { independence, } \\
\text { outliers and } \\
\text { homoscedaticity) }\end{array}$ & $\begin{array}{l}\text { Low wealth } \\
\text { asset bases } \\
\text { and disability } \\
\text { to deal with } \\
\text { financial } \\
\text { stress are } \\
\text { obstacles to } \\
\text { personal } \\
\text { financial well- } \\
\text { being. }\end{array}$ \\
\hline $\begin{array}{c}\text { Under } \\
\text { developed } \\
\text { countries } \\
\text { (Pakistan) }\end{array}$ & $\begin{array}{l}\text { IV } \\
\text { - Self-pelf-control } \\
\text { - Financial } \\
\text { Literacy } \\
\text { - Personal } \\
\text { Financial } \\
\text { Behaviour } \\
\text { Mediator } \\
\text { - Financial } \\
\text { Behaviour } \\
\text { DV } \\
\text { Financial } \\
\text { wellness }\end{array}$ & $\begin{array}{l}416 \text { people } \\
\text { from } \\
\text { educational } \\
\text { institutions, } \\
\text { corporate } \\
\text { sectors, food } \\
\text { courts }\end{array}$ & $\begin{array}{l}\text { - Questionnaire } \\
\text { - G. Power Software } \\
\text { - SPSS }\end{array}$ & $\begin{array}{l}\text { Financial well- } \\
\text { being is } \\
\text { influenced by } \\
\text { both self- } \\
\text { control and } \\
\text { financial } \\
\text { literacy. }\end{array}$ \\
\hline
\end{tabular}

Notes: IV is an acronym for independent variable. DV stands for Dependent Variable. 
Table 2.0 Compilation of Definitions of Financial Well-Being (From years 1976 - 2017)

\begin{tabular}{|c|c|}
\hline Author & Introduction on Definitions of FWB \\
\hline Strumpel (1976) & $\begin{array}{l}\text { Extends beyond temporary pleasures to include individuals' satisfaction with their income and savings, } \\
\text { as well as their views of opportunities, capacity to "make ends meet," sense of material stability, and } \\
\text { sense of the reward distribution system's fairness. }\end{array}$ \\
\hline Furgusson et al. (1981) & Financial well-being can be defined by financial income and asset accumulation. \\
\hline Williams (1983) & $\begin{array}{l}\text { Designate financial well-being as a function of material and spiritual aspects of one's financial status due } \\
\text { to changes in people in improving people's life and living standards. }\end{array}$ \\
\hline Hayhoe et al. (2000) & $\begin{array}{l}\text { Consider a person's sense of financial well-being to be contentment, which is a response to his or her } \\
\text { financial circumstances. }\end{array}$ \\
\hline Porter (1990) & $\begin{array}{l}\text { Financial well-being is one's behaviour towards financial condition based on objective aspect and judge, } \\
\text { with regards to the individual's standard. }\end{array}$ \\
\hline Joo (1998) & $\begin{array}{l}\text { Defines financial well being based on one's satisfaction and varies with the changes accordingly to the } \\
\text { level of status of people. It is a perception of an individual's financial situation that is financially free } \\
\text { from worry, healthy and happy. } \\
\text { Economic Well-Being Model: } \\
\text { Financial health is comprised of three components: i. financial behaviour, ii. financial satisfaction, and } \\
\text { iii. financial or subjective evaluations of one's financial situation (e.g. : financial attitude). }\end{array}$ \\
\hline Goldsmith (2000) & $\begin{array}{l}\text { Financial well-being is defined as an individual's or family's financial adequacy and security, which } \\
\text { guards against economic threats such as job loss, illness, insolvency, poverty, and retirement destitute. }\end{array}$ \\
\hline Van Praag et al. (2003); & Individual happiness in six areas: business, finance, home, leisure, health, and environment. \\
\hline
\end{tabular}


INTERNATIONAL JOURNAL OF ACADEMIC RESEARCH IN BUSINESS AND SOCIAL SCIENCES

Vol. 11, No. 19, Youth and Community Wellness, 2021, E-ISSN: 2222-6990 @ 2021 HRMARS

\begin{tabular}{|l|l|}
\hline $\begin{array}{l}\text { Shim, Xiao, Baber \& Lyons } \\
(2009)\end{array}$ & $\begin{array}{l}\text { Financial well-being is defined as satisfaction with one's current economic situation and amount of } \\
\text { debt. }\end{array}$ \\
\hline Rath and Harter (2010) & $\begin{array}{l}\text { Well-being involves five fundamental elements. One of the important elements is financial well-being, } \\
\text { aside from community, physical, carrier and social. }\end{array}$ \\
\hline $\begin{array}{l}\text { Zaimah, Masud Haron, } \\
\text { Othman, Awang and Sarmila } \\
(2013)\end{array}$ & Employee's financial well being and productivity have a significant association with each other. \\
\hline $\begin{array}{l}\text { Gerrans, Spellman \& } \\
\text { Campitelli (2014) }\end{array}$ & Invariably conceptualised financial well-being as the subjective appraisal \\
\hline (CFPB, 2017: 13) & $\begin{array}{l}\text { The financial well-being of individuals resembles individual responsiveness on: } \\
\text { (1) How individuals regulate their daily and monthly finances, } \\
\text { (2) The ability to handle financial vulnerability, } \\
\text { (3) Individuals' manage their financial goals; and } \\
\text { (4) financial freedom to relish life. }\end{array}$ \\
\hline
\end{tabular}

Source: Authors compilations 


\section{The Factor Influences Affecting the Financial Well Being}

There were various variables used to examine the financial well-being of the households-for instance, household's income, credit rationing, economic, social and external effect. However, financial well-being cannot be measured simply by looking at these few variables. It encompasses multiple determinants of financial well-being and needs to look from different angles. Thus, each country may have different variables, which are better to define and examine their own country's financial well-being. Therefore, Table 1 summarises reference variables, sample, methods or sampling techniques and findings presented by various countries.

\section{Conceptualizations and Definitions of Financial Well-being}

Financial well-being has been defined in various ways; in economic, services marketing, social, household level, financial counselling and planning, developmental psychology, and consumer decision making (Aggarwal, 2014; Brüggen et al., 2017). However, this paper focuses specifically on the determinants and measurements of financial well being at the household level in selected three states -develop, developing and underdeveloped countries. On the contrary, this paper attempts to fill the gap to designate the commonly used variables in past literature.

Previously, the definition of financial well-being was commonly on happiness or satisfaction with one's financial ownership. However, the definitions have shifted towards an individual's attentiveness to improving people's quality of life and standard of living (Amirah Shazana, 2021).

\section{Objectives \& Subjective Definitions of Financial Well-Being}

Frequently, numerous kinds of literature defined and measured financial well-being for a specific purpose. Strumpel (1976), however, defined that "financial well-being goes beyond transitory satisfactions to encompass individuals' satisfaction with income and savings, as well as perceptions of opportunities, ability to "make ends meet," sense of material security, and sense of fairness of the reward distribution system" (Strumpel, 1976: 5).

Even though this topic has been well discussed since the 1970s, there is no mutual agreement on elusive concepts and definitions of well-being. Due to that matter, Consumer Financial Protection Bureau (2017) has put an effort to construct a comprehensive definition that takes into consideration on consumers' perception and is relevant to be used across a different range of individual circumstances:

"Described as a state of being in which an individual is able to fully meet present and ongoing financial commitments, is confident in their financial future, and is able to make decisions that allow them to live life to the fullest." (CFPB, 2017: 13).

Precisely, the financial well-being of individuals resembles individual responsiveness on (1) how individuals regulate their daily and monthly finances, (2) ability to handle financial vulnerability, (3) manage their financial goals; and (4) financial freedom to relish life. Despite the diversity of life and goals of individuals, these components consist of the two essential elements, security, and freedom of choice, in the present-day and forthcoming (CFPB, 2017). 
Prior to that definition, many researchers attempt to group financial well-being into three distinctive groups - both objective and subjective well being, or either objective or subjective well-being. There is an abundance of research on objective financial well-being compared to research on subjective well-being ${ }^{1}$. Income is the most commonly used quantitative indicator of objective financial well-being (Bonke \& Browning, 2009; Arber, Fenn \& Meadows, 2014; Zyphur et al., 2015). For example, Ferguson (2006) has well described financial well-being as financial income and asset. On top of the reason why income is commonly used is that income contributes most to economic well-being. It measures the fundamental factors related to an individual's attainment, prestige, security, and financial facet.

Similarly, other studies comprised financial information on the level of debt, financial expenses, ratio, household consumption, asset, and ownership Aggarwal (2014); Greninger, In spite of this, Porter (1990) stressed that financial well-being is defined as a person's behaviour toward financial circumstances that is based on objective aspects and judged in relation to an individual standard.

However, besides objective and subjective measures, a researcher's significance is to perceive beyond people's satisfaction. Porter and Garman (1993) did emphasize the importance of further investigation upon individuals' perceptions using qualitative strategy indicators. According to Porter and Garman (1993),

The measurement is further strengthened by value-related qualitative indicators and assessments of the financial situation based upon selected standards of comparison. A sense of financial well-being depends not only upon objective and subjective measures of the financial situation, but on an individual's (a) perception of life in general, (b) perception of objective attributes of the financial situation after comparing those attributes against selected standards of comparison, and (c) perhaps other factors.

(Porter \& Garman, 1993: 161-162)

Apart from that, Williams (1983) did emphasise the characterisation of financial wellbeing as a function of material and spiritual aspects of one's financial status due to changes in people in improving life and living standard. However, Hayhoe et al (2000) defined financial well-being as individual fulfilment, the response of an individual concerning his financial condition. High satisfaction is said to contribute to high financial well-being, and it is the belief that high financial well-being leads to the good well-being of an individual.

As discussed earlier, objective financial well-being postulates the evidence of individual's facet of financial condition (Norvilitis et al., 2003; O'Neill et al., 2005), whilst the definition of subjective financial well-being is perceived with individual's, reaction such as happiness and satisfaction towards their financial condition (Patel \& Wolfe, 2019; Joo \& Grable, 2004; Kahneman \& Deston, 2010; Greninger et al., 1996). These indications are crucial as they could help researchers to examine people's perceptions.

1 The keyword search for 'objective financial well-being' is 303,410, and 'subjective financial well being' was only found 79,616 results. Search completed on October 14, 2021, using Web of Science Thomson Reuters online searches. 
Although there is an abundance of research using these two approaches to explain and evaluate financial well-being, there are as well studies that emphasise a more subjective and less objective approach when defining financial well-being. Researchers such as Shim et al (2009) have focused on the financial well-being of the adolescent and used financial debt as a measurement of their objective well-being and financial satisfaction along with managing financial stress as subjective well-being. On the other hand, Shim et al (2009) has characterised financial well-being as gratification with the individual's existing economic standing and level of debt.

On top of that, Goldsmith (2000) defines financial well-being at a different angle, whereby he describes financial well-being as financial adequacy and safety of individual or family that protects the person against economic risk such as unemployment, illness, bankruptcy, poverty and destitution in retirement. Meanwhile, Zaimah et al (2018) highlight the employee's financial well-being and productivity have a significant association with each other. Gerrans et al (2014) invariably conceptualised financial well-being as a subjective appraisal.

Rendering to Garman et al (2004), the financial well-being of individuals can be comprehended differently and accordingly. In other words, although they are defined under the same objective financial well-being approach (e.g., asset and income), financial well-being could be measured depending on the researcher's intention on what they compared and preferred. For example, the reported rates of material hardship and financial struggles were extremely high in households that reported lower levels of financial well-being. In comparison, these financial difficulties were lower in households with higher levels of financial well-being. At the same time, higher incomes did not always correspond to higher well-being levels for all individuals.

Consequently, individuals in a similar financial state might evaluate their financial well-being more or less positively. Most of these findings have highlighted the significance of individual personalities (Fah et al., 2010) and financial attitude (Shim et al., 2009) that eventually affect individuals' subjective evaluation of their financial well-being. Malone et al (2010) confirmed that individuals might experience different assessments of their financial well-being, founded on their lifestyle or their behaviour in attaining risk. Other indicators of the subjective designation of financial well-being, such as the ability to manage expenditures and overheads, gratification towards individuals savings and investment, and stress management on financial debt, are also commonly used (Kim and Garman, 2003).

Mokhtar and Husniyah (2017) highlighted the importance of research on subjective well-being. The extended analysis and result carried out will provide a clear understanding of the responses of individuals and families based on their present and henceforward current financial state. Apart from that, researchers, financial educationalists, policymakers, and practitioners might be interested in looking upon the impact factors applied to financial wellbeing in different measures and circumstances.

In summary, after much in-depth literature has been explored, it can be concluded that the subjective approach postulates a clearer understanding of individuals and family financial conditions. The subjective method, in addition, is more extensive. As a result, it is 
more appropriate than the objective method to describing and assessing the complex and personal phenomena of financial well-being since it captures individuals' non-financial concerns.

\section{The Factor Influences Affecting the Financial Well Being}

Financial well-being is a crucial research topic because it examines how consumers manage their money, spend, save, and invest (Nanda \& Banerjee, 2021). The ability of a country's policymakers to move its citizens to a higher level of financial well-being is frequently used to measure the country's economic growth. Many early academic studies in the field of financial well-being emphasised objective economic measures, such as consumer income, savings, investment, credit score, credit card debt, regular mortgage payments, and tax payments (Schmeiser \& Seligman, 2013; Soman \& Cheema, 2002). Alternatively, the subjective evaluation of financial well-being is based on the consumer's self-report of his or her temperament, attitude, belief, and money management activities (Brüggen et al., 2017; Netemeyer et al., 2018). Managing cash, credit, and savings are daily financial behaviours that impact a person's financial well-being or financial vulnerability (Shazana et al., 2020, 2021; Dew \& Xiao, 2011). Hence, understanding the conceptual development of the focal subjective financial well-being construct, its antecedents, repercussions, and future study paths will interest consumer behaviour researchers, financial institutions, non-profit organisations, businesses, and government policymakers.

Over the past decades, various variables have been applied to examine the financial well-being of households, for example, household income, financial debt, economic, social, financial health, and psychology (Nickerson et al., 2007; Sabri \& Zakaria, 2015a; 2015b; Shim et al., 2009; Arendt \& Brettel, 2010, Por et al., 2011). However, over the years, researchers have gone beyond transitory satisfactions to comprehend that an individual has perceived pleasure and gratification towards the ability to make ends meet (Strumpel, 1976). The qualitative approach also plays a vital role in measuring a respondent's satisfaction with life. It helps explain the perceived level of financial well-being in previous research studies (Porter \& Garman, 1993).

However, financial well-being cannot be measured only by considering these few variables. It encompasses multiple determinants of financial well-being, and researchers should focus on different angles. Hence, every country might apply distinctive variables suited to describe and examine the country's financial well-being. Consequently, Table 1 summarises variables, samples, sampling techniques, and findings presented by various countries.

The report in developed countries has shown that 74 per cent of United States adults were found relatively satisfied with their financial condition (Anderson et al., 2015). Surprisingly, issues on financial strains were reported as the highest problem confronted by the U.S household, especially on financial stress management (Board of Governors of the Federal Reserve System, 2018). CFBD also (2015b) reported that rates of material hardship and financial struggles were extremely high in households and thus conveyed lower levels of financial well-being. On the contrary, households with low financial stresses were found to have higher levels of financial well-being. However, a researcher needs to note that higher incomes did not always portray a higher well-being level for every individual. 
On the other hand, a study was conducted in Sweden, 2017 to determine whether personal disparities, self-control, and non-cognitive factors predict the Swedish population's financial behaviour and well-being. Questionnaires were developed and distributed among 2063 respondents. Samples used moderately represent a distinct population in Sweden, postulates of 1048 women and 1015 men, with the age of 20-75 and mean age of 49 years. The findings show that self-control, optimism, and deliberative thinking are confirmed to influence an individual's financial behaviour as well as financial well-being. People perceived with good self-control were more likely to practices good financial savings for future circumstances and retirement plans. Meanwhile, optimistic respondents worry less about the financial problem and are determined with their finances (Strömbäck et al., 2017). Oechssler et al (2009) supported this view, inscribes that self-control leads to a healthful, financially balanced, and good psychological life, leading to positive financial wellness.

Strong evidence based on the Organisation for Economic Co-operation and Development, OECD (2016) research has revealed that Malaysia possesses the highest number of public employees in the world. Since financial well-being might vary throughout the individual, a third study conducted in a developing country in Malaysia by Mokhtar and Husniyah (2017) is reviewed to seek the financial well-being among the public administration.

This study employed a quantitative analytic approach with a sample of 500 public employees from selected government ministries in Putrajaya, respectively. A web-based online survey is constructed and shared amongst respondents. The questionnaire was carried out for the research study with constant control variables, focusing on financial stress, financial behaviour, financial knowledge, work environment, and locus of control to predict their effect on financial well-being, particularly psychological, social, physical and emotional. This study underlined the research limitation by applying the work environment from the personal financial perspective (Mokhtar \& Husniyah, 2017). The work environment is used to fill the gap in knowledge contribution whereby previously variable on the work environment is often associated with organisational behaviour context. Findings found that financial stress, work environment, and financial behaviour had the most significant influence on the performance and level of the employees' financial well-being. The research outcome came out with lower financial stress, leads to a positive working environment, and good financial behaviour, thus enhancing the employee's financial well-being.

Aforementioned in that evidence, different variables have been used to examine the employee's financial well-being. Determinant, such as financial literacy, poor financial management, and stress towards finance is commonly used by the developing countries (Delafrooz \& Paim, 2011; Sabri \& Falahati, 2012 mostly because Malaysia's policy economy are shifting their focus towards developing high-income country and increasing its effort to eradicate poverty (Mayan, Nor \& Samat, 2017).

Some effort has been made to use other variables; studies in Iran, Taft et al (2013) research assess the relationship between financial literacy, financial well-being, and financial concerns. Apart from that, the study also seeks upon objective measurement, a correlation between demographic characteristics between age, gender, marital status, and level of education towards their effect on financial well-being. The research was conducted composed of a sample of lecturers at the University of Iran. Data were analysed using SPSS. 
The outcome of this research found a positive relationship between age and financial wellbeing and age and financial literacy. Data revealed a significant relationship between age and education towards financial literacy and good financial well-being.

Meanwhile, in terms of gender, married people and men are more financially literate compared to women. The researcher also indicates that higher financial literacy leads to greater financial well-being and fewer financial concerns. The central core findings of this study emphasise that good financial well-being leads to less financial concern.

Last but not least, prior studies in under-developed countries, especially in Pakistan by Younas et al (2019), were constructed among 416 respondents from educational institutions, corporate sectors, and food courts in Pakistan to emphasise self-control. Financial literacy leads to a higher financial well being. The paper concludes that self-control and financial literacy affect financial well-being through financial behaviour. The data shows that better self-control and financial literacy indicate better financial well-being, which explains how financial literacy significantly impacts financial well-being.

However, according to Younas et al (2019), the direct impact of self-control on financial well-being presents a non-significant impact. Meanwhile, the association between financial behaviour and financial well-being has a greater degree of significance than the relationship between financial literacy and self-control. This paper, however, did highlight the importance of understanding the role of self-control and financial behaviour, as this behaviour commits to building a good character of the individual to be more confident in managing their financial facet and preparing future retirement.

In summary, although there is an abundance of research that uses different variables and comes out with a different result, one may consider the dissimilarities in period and place of investigation. These differences can indicate different meanings and measures of an individual's financial well-being and their relationship between variables (Taft et al., 2013).

\section{Conclusion}

Based on the review of these findings and literature, it can be concluded that financial well-being is a broad concept that has been defined in various ways. Definitions can generally be divided into two broad categories: objective and subjective. Objective definitions could be demographic characteristics, socio-economic status, and household expenditure. In other words, objective definitions also attribute to the quantitative indicators of financial conditions such as money income and family size.

Throughout this paper, the researcher did argue that individuals' financial well-being can also be comprehended differently. Preferentially, although they are defined under the same objective approach (e.g., asset and income), financial well-being could be measured depending on the researcher's intention on what they compared and preferred.

Satisfaction and happiness, by contrast, would be subjective terms. However, this paper helps explain the variances in perceived financial well-being across different variables among three states of countries - developed, developing, and under-developed countries. Hence, the evidence review revealed that the high attainment of individuals characterizes 
high financial well-being in fulfilling their requirement needs, along with high satisfaction and gratitude with their financial status.

In summary, the literature suggests that a subjective approach is a more comprehensive way of capturing non-financial issues and is therefore considered a more inclusive method than an objective approach in defining and measuring a complex and personal phenomenon such as financial well-being.

\section{Acknowledgement}

The authors would like to express their appreciation to the Ministry of Higher Education Malaysia for their contribution to this research, Long Term Research Grant Scheme-Malaysia Research University Network (LRGS-MRUN), project code (MRUN-2019-001/4) entitled "Determinants of Financial Well-being among B40 Households".

\section{References}

Aggarwal, S. (2014). Developing an index for measuring financial well-being in a geography. IFMR Finance Foundation.

Anderson, N. B., Belar, C. D., Breckler, S. J., Nordal, K. C., Bal- lard, D. W., Bufka, L. F., \& Wiggins, K. (2015, February). Stress in America: Paying with our health. American Psychological Association.

Arber, S., Fenn, K., \& Meadows, R. (2014). Subjective financial well-being, income and health inequalities in mid and later life in Britain. Social Science \& Medicine, 100, 12-20.

Arendt, S., \& Brettel, M. (2010). Understanding the influence of corporate social responsibility on corporate identity, image, and firm performance. Management Decision, 48(10), 1469-1492.

Aripin, S. N., \& Puteh, F. (2017). Financial wellness and quality of life among young employees. Journal of Administrative Science Special Edition: Socio-Economic Issue, 14(3), 1-13.

Benjamin, D. J., Heffetz, O., Kimball, M. S., \& Szembrot, N. (2014). Beyond happiness and satisfaction: Toward well-being indices based on stated preference. American Economic Review, 104(9), 2698-2735.

Bonke, J., \& Browning, M. (2009). The distribution of financial well-being and income within the household. Review of Economics of the Household, 7(1), 31-42.

Brüggen, E. C., Hogreve, J., Holmlund, M., Kabadayi, S., \& Löfgren, M. (2017). Financial wellbeing: A conceptualization and research agenda. Journal of Business Research, 79, 228237.

Chan, K. W., Yim, C. K., \& Lam, S. K. (2010). Is Customer Participation in Value Creation a Double Edged Sword? Evidence from Professional Financial Services across Cultures. Journal of Marketing, 74(3), 48-54.

Chen, P., \& Finke, M. (1996). Negative Net Worth and the Life Cycle Hypothesis. Financial Counseling and Planning, 7(1), 87-95.

Consumer Financial Protection Bureau. (2015b). Measuring Financial Well-Being: A Guide to Using the CFPB Financial Well-Being Scale. Retrieved on July 25, 2018 from https://files.consumerfinance.gov/f/201512_cfpb_financialwell-being-user-guidescale.pdf.

Delafrooz, N., \& Paim, L. H. (2011). Determinants of financial wellness among Malaysia workers. African Journal of Business Management, 5(24), 10092-10100. 
DeVaney, S. A., \& Lytton, R. H. (1995). Household insolvency: A review of household debt repayment, delinquency, and bankruptcy. Financial Services Review 4(2), 137156 https://doi.org/10.1016/1057-0810(95)90008-X.

Dew, J., \& Xiao, J. (2011). The financial management behaviour scale: Development and validation. Journal of Financial Counseling and Planning, 22, 43-59.

Ferguson, K. M. (2006). Social capital and children's wellbeing: a critical synthesis of the international social capital literature. International Journal of social welfare, 15(1), 218.

Fergusson, D. M., Horwood, L. J., \& Beautrais, A. L. (1981). The measurement of family material wellbeing. Journal of Marriage and Family, 43(3), 715-725. http://dx.doi.org/10.2307/351771

Fletcher, C. N., \& Lorenz, F. O. (1985). Structural influences on the relationship between objective and subjective indicators of economic well-being. Social Indicators Research, 16(3), 333-345.

Garman, E. T., Sorhaindo, B., Bailey, W., Kim, J., \& Xiao, J. (2004). Financially distressed credit counseling clients and the incharge financial distress/financial well-being scale. Proceedings of the Eastern Regional Family Economics and Resource Management Association Conference.

Gerrans, P., Speelman, C. P., \& Campitelli, G. (2014). The relationship between personal wellness and financial well-being: A structural equation modelling approach. Journal of Family and Economic Issues, 35(2), 145-160.

Goldsmith, E. B. (2000). Resource management for individual and family. Belmont, CA: Wadsworth learning.

Greninger, S. A., Hampton, V. L., Kitt, K. A., And Achacoso, J. A. (1996). Ratios and benchmarks for measuring the financial well-being of families and individuals. Financial Services Review 5(1), 57-70 https://doi.org/10.1016/S1057-0810(96)90027-X

Hayhoe, C., Leach, I., Turner, P., Bruin, M., \& Lawrence, F. (2000). Difference in spending Habits and credit card use of college students. Journal of Consumer Affairs, 34, 113-133. http://dx.doi.org/10.1111/j.1745-6606.2000.tb00087.x

Hogarth, J., Anguelov, C., \& Lee, J. (2004). Why Don't Households Have a Checking Account? The Journal of Consumer Affairs, 38, 1-34.

Joo, S. -H., \& Grable, J. E. (2004). An exploratory framework of the determinants of financial satisfaction. Journal of Family and Economic Issues, 25(1), 25-50. SEẸ.

Joo, S. (1998). Personal financial wellness and worker productivity. Unpublished doctoral dissertation, Virginia Polytechnic Institute and State University, Blacksburg.

Kahneman, D., \& Deaton, A. (2010). High income improves evaluation of life but not emotional well-being. Proceedings of the National Academy of Sciences of the United States of America, 107(38), 16489-16493.

Kim, J., \& Garman, E. T. (2003). Financial stress and absenteeism: An empirically derived model. Financial Counseling and Planning, 14(1), 31-42.

Malone, K., Stewart, S. D., Wilson, J., \& Korsching, P. F. (2010). Perceptions of financial wellbeing among American women in diverse families. Journal of Family and Economic Issues, 31(1), 63-81.

Mayan, S. N. A., Nor, R. M., Samat, N. (2017) Challenges to the household income class B40 increase in developed country towards 2020 case study: Penang. International Journal of Environmemt, Society and Space, 5(2), 35-41.

Mokhtar, N., \& Husniyah, A. R. (2017). Determinants of financial well-being among public 
employees in Putrajaya, Malaysia. Pertanika J. Soc. Sci. Hum, 25, 1241-1260.

Mugenda, D. M., Hira, T. K., \& Fanslow, A. M. (1990). Assessing the causal relationship among communication, money management practices, satisfaction with financial status, and satisfaction with quality of life. Lifestyles: Family and Economic Issues, 11, 343-360.

Nanda, A. P., \& Banerjee, R. (2021). Consumer's subjective financial well-being: A systematic review and research agenda. International Journal of Consumer Studies.

Nickerson, C., Schwarz, N., \& Diener, E. (2007). Financial aspirations, financial success, and overall life satisfaction: Who? And how?. Journal of Happiness Studies, 8(4), 467-515.

Norvilitis, J. M., Szablicki, P. B., \& Wilson, S. D. (2003). Factors influencing levels of credit- card debt in college students. Journal of Applied Social Psychology, 33(5), 935-947.

O'Neill, B., Sorhaindo, B., Xiao, J. J., \& Garman, E. T. (2005). Financially distressed consumers: Their financial practices, financial well-being, and health. Financial Counseling and Planning, 16(1), 73-87.

OECD. (2016). Household savings forecast (Indicator). retrieved from doi: https://data.oecd. org/hha/household-savings-forecast.htm

Oechssler, J., Roider, A., \& Schmitz, P. W. (2009). Cognitive abilities and behavioural biases. Journal of Economic Behaviour \& Organization, 72(1), 147-152.

Paim, L., \& Yahaya, N. (1997). Pendapatan dan pembelanjaan pekerja migran wanita: suatu perbandingan antara sektor awam, industri dan jualan. Journal Pertanika Social \& Human. 5(2). 83-91.

Patel, P. C., \& Wolfe, M. T. (2019). Money might not make you happy, but can happiness make you money? The value of leveraging subjective well-being to enhance financial wellbeing in self-employment. Journal of Business Venturing Insights, 12, 134.

Por, J., Barriball, L., Fitzpatrick, J., \& Roberts, J. (2011). Emotional intelligence: its relationship to stress, coping, well-being and professional performance in nursing students. Nurse education today, 31(8), 855-860:

Porter, N. M. (1990). Testing a model of financial wellbeing. Financial Counseling and Planning, 4, 135-164.

Porter, N. M., \& Garman, E. T. (1993). Testing a conceptual model of financial well-being. Financial Counseling and Planning, 4, 135-165.

Porter, N. M., \& Garman, E. T. (1993). Testing a conceptual model of financial well-being. Financial Counseling and Planning, 4, 135-165.

Rath, T., Harter, J. K., \& Harter, J. (2010). Wellbeing: The five essential elements. Simon and Schuster.

Rutherford, L. G., \& Fox, W. S. (2010). Financial wellness of young adults age 18-30. Family and Consumer Sciences Research Journal, 38(4), 468-484.

Sabelhaus, J., \& Manchester, J. (1995). Baby Boomers and Their Parents: How Does Their Economic Well-Being Compare in Middle Age?. Journal of Human Resources, 791-806.

Sabri, M. F., \& Falahati, L. (2012), Estimating a model of subjective financial well-being among college students. International Journal of Humanities and Social Science, 2(18), 191-199.

Sabri, M. F., \& Zakaria, N. F. (2015a). The influence of financial literacy, money attitude, financial strain and financial capability on young employees' financial well-being. Pertanika Journal of Social Sciences and Humanities, 23(4), 827-848.

Sabri, M. F., Cook, C. C., \& Gudmunson, C. G. (2012). Financial well-being of Malaysian college students. Asian Education and Development Studies, 1(2), 153-170.

Schmeiser, M. D., \& Seligman, J. S. (2013). Using the right yardstick: Assessing financial literacy measures by way of financial well-being. CFS Research Brief, 43(2), 243-262. 
https://doi.org/10.1111/joca.12010.

Soman, D., \& Cheema, A. (2002). The effect of credit on spending deci- sions: The role of the credit limit and credibility. Marketing Science, 21(1), 32-53. https://doi.org/10.1287/mksc.21.1.32.155

Squire, L. (1991). Poverty and adjustment in the 1980s. World Bank Policy Research Bulletin, 2(2), 1-5.

Strömbäck, C., Lind, T., Skagerlund, K., Västfjäll, D., \& Tinghög, G. (2017). Does self-control predict financial behaviour and financial well-being?. Journal of Behavioural and Experimental Finance, 14, 30-38.

Strumpel, B. (Ed.). (1976). Economic means for human needs. Ann Arbor, MI: Institute for Social Research.

Sun, S., Kondratjeva, O., Roll, S. P., Despard, M., \& Grinstein-Weiss, M. (2018). Financial WellBeing in Low-and Moderate-Income Households: How Does It Compare to the General Population?. Social Policy Institute, 18, 1.

Taft, M. K., Hosein, Z. Z., Mehrizi, S. M. T., \& Roshan, A. (2013). The relation between financial literacy, financial wellbeing and financial concerns. International Journal of Business and Management, 8(11), 63.

Van Praag, B. M., Frijters, P., \& Ferrer-i-Carbonell, A. (2003). The anatomy of subjective wellbeing. Journal of Economic Behaviour \& Organization, 51(1), 29-49.

Williams, F. I. (1983). Money income, no money income, and satisfaction as determinants of perceived adequacy of income. Paper presented at the perceived economic wellbeing symposium, Urbana.

Xiao, J. J. (Ed.). (2008). Handbook of consumer finance research. (p. 70). New York: Springer.

Yin-Fah, B.C., Masud, J., Hamid, T.A. and Paim, L. (2010), Financial well-being of older peninsular Malaysians: a gender comparison. Asian Social Science, 6(3), 58.

Younas, W., Javed, T., Kalimuthu, K. R., Farooq, M., Khalil-ur-Rehman, F., \& Raju, V. (2019). Impact of self-control, financial literacy and financial behavior on financial wellbeing. The Journal of Social Sciences Research, 5(1), 211-218.

Zaimah, R., Masud, J., Haron, S. A., \& Awang, A. H. (2018). Financial Well-being of Married Workers in Malaysia.

Zyphur, M. J., Li, W. D., Zhang, Z., Arvey, R. D., \& Barsky, A. P. (2015). Income, personality, and subjective financial well-being: the role of gender in their genetic and environmental relationships. Frontiers in psychology, 6, 1493. 